Vol.17, No.62, January 2022, 219-236

\title{
EFFECT OF USING GLASS POWDER AS A PARTIAL REPLACEMENT OF CEMENT ON CONCRETE PROPERTIES
}

\author{
Mohamed Hamdy Abo El-Kassem ${ }^{1}$, Osama Mahmoud Mohamed ${ }^{2}$, Mohamed Zakaria Abd El- \\ Hamid $^{3}$, \\ ${ }^{1}$ Bachelor of Civil Engineering, teaching assistant, New Cairo Academy \\ ${ }^{2,3}$ Department of Civil Engineering, Aswan University \\ *Corresponding Author E-mail:m.Hamdy199473@yahoo.com
}

Received :19 Oct. $2021 \quad$ Accepted:23 Dec. 2021

\begin{abstract}
The cement industry causes many environmental damages, because its manufacture causes the emission of greenhouse gases to the atmosphere, such as $\mathrm{CO}_{2}$, which leads to the global warming. Therefore, the search for new building material has become one of the most prominent engineering researches supported by construction companies in the world. This research studies the effect of using waste glass powder as a partial substitute of cement at rates from 5\% to $20 \%$ at a fixed increase rate of $5 \%$ on some of different properties of concrete with grade M 35 by using sikament $-163 \mathrm{M}$ is used as a super plasticizer by $1 \%$ from weight of cement. Laboratory tests were conducted to compare the performance of the control sample and the samples containing waste glass powder, and this was done on fresh concrete to determine its workability by slump test and also the tests were conducted on hardened concrete to determine the compressive strength at the ages of 7, 28, 56 days, as well as determining the flexural strength, water penetration resistance of concrete, Modulus of Elasticity test and XRD analysis test of all samples at the age of 28 days. The results clearly confirmed an increase in the workability of concrete with an increase in the percentage of waste glass powder in the mixture. It also showed a good improvement in the compressive strength, flexural strength, modulus of elasticity, and the optimum percentage of improvement was $15 \%$ WGP. And then it declined. The XRD test actually proved that the glass powder has a pozzolanic reaction with cement hydrate. In the end, it was found that the penetration
\end{abstract}


of water into the sample decreases by increasing the content of the glass powder in the mixture.

KEYWORDS: Waste Glass Powder, Pozzolanic Reaction, Workability, Global Warning, Water penetration.

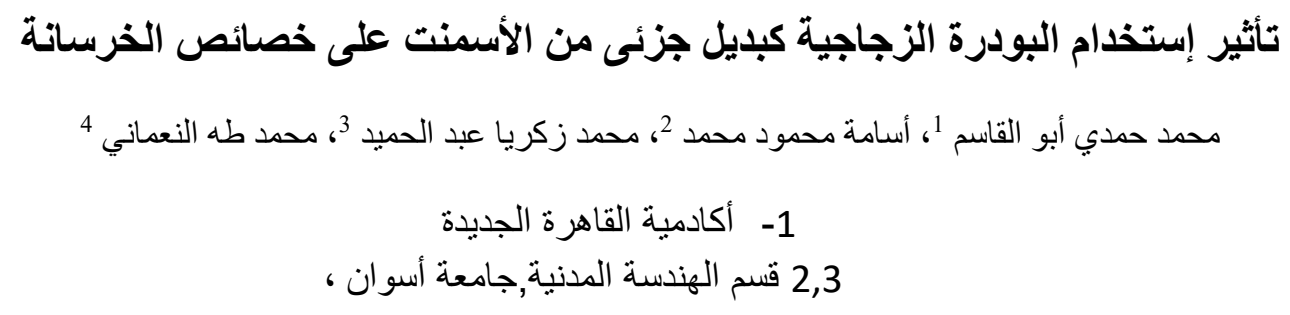

*Corresponding Author E-mail:m.Hamdy199473@yahoo.com

صناعة الأسمنت تسبب العديد من الأضرار البيئية, لأن تصنيعها يؤدى إلي إنبعاث الغازات الدفيئة إلي الغلاف الجوى, مثل ثانى أكسيد الكربون, مما يؤدي إلي الإحترار العالمي. لذلك أصبح البحث عن مواد البناء الجديدة أحد

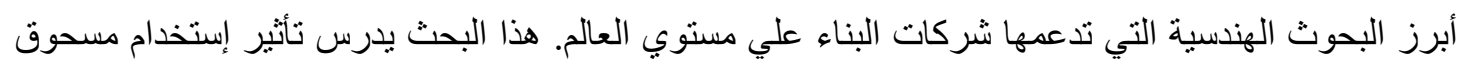
زجاج النفايات كبديل جزئى للأسمنت بمعدلات تتراوح من 5\% إلي 20٪ بمعدل زيادة ثابت 5\% علي بعض الخصائص المختلفة للخرسانة ذات الرنبة 35 بإستخدام سيكامنت 163 حيث يستخدم كملدن فائق بنسبة 1\% من وزن الأسمنت. و أجريت الإختبار ات المعملية لمقارنة أداء عينة التحكم و العينات التي تحتوي علي نفايات مسحوق الزجاج, وتم ذلك علي الخرسانة الطازجة لتحديد قابليتها للتشغيل عن طريق إختبار الهبوط, كما أجريت الإختبارات

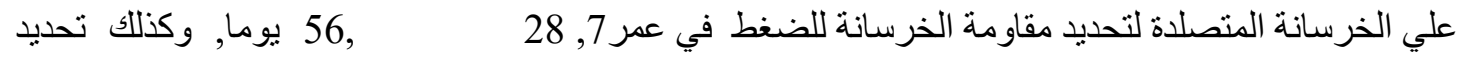
مقاومة الإنحناء ومقاومة نفاذ الماء إلي الخرسانة ومعاير المرونة وتحليل العينة عن طريق أشعة إكس لجميع

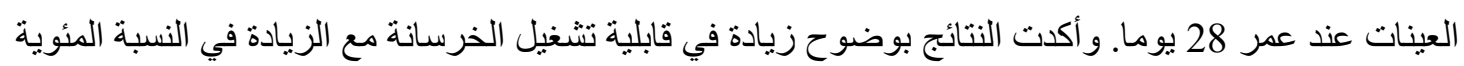
لمسحوق نفايات الزجاج في الخليط.كما أظهرت النتائج تحسنا جيدا علي مقاومة الضغط ومقاو مة الإنحناء ومعاير

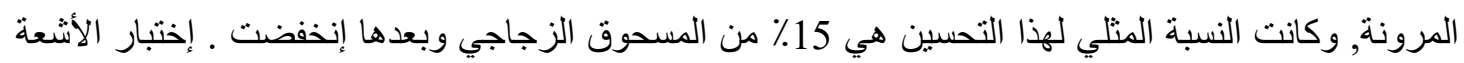

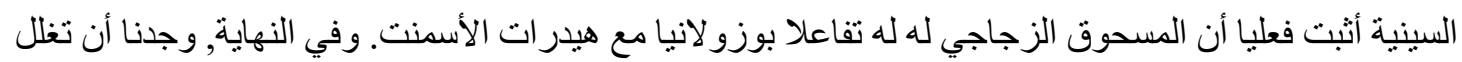
الماء في العينة يقل بزيادة محتوي المسحوق الزجاجي في الخليط. 


\section{INTRODUCTION}

Concrete actually became a major building material worldwide, because it is used in many fields and at the same time is economical; but it has impacts on the environment [1], these effects are harmful because the main component of concrete industry is cement; which produces green houses gas emissions From its manufacture, for example of these gases is carbon dioxide (CO2); which causes global warming [2] . The use of supplementary cementitious materials (SCMs) as a partial substitute for cement is a good way to reduce the environmental impacts of the cement industry, and several studies have also indicated the success of using supplementary cementitious materials (SCMs), and for examples of these materials; silica fume (S.F),fly ash (F.A),ground granulated blast furnace slag (G.G.B.S) [2,3] this materials; which can improve concrete durability, early and long term strength, workability and economy[4]. Researchers noted that glass has a chemical composition and phase comparable to traditional (SCMs) [5-7] also, previous researchers indicated in their study that these replacement materials did not achieve as commercial success as the glass powder [8].

Millions of tons of waste glass are produced annually in all regions of the world $[8,9]$. It is a substance that is not composed in nature and is buried in the ground. Thus it has harmful environmental effects and is also an expensive process. The sustainable building practice authority strives to create a healthy environment in a responsible manner in order to conserve resources and the environment, through the use of wasted glass in various industries [10]. This is done by using a waste glass powder as a partial replacement of cement, and it used as a large or a small aggregate in concrete. The effect of using waste glass in concrete is of two types ,the first type is the alkalinesilica reaction (ASR), which causes harm in concrete, and the second type is a pozzolanic reaction, which works to improve properties of the concrete [11], The alkali-silica reaction is usually accompanied with coarse glass particles containing amorphous silica where a devastation of the silica network happen to relief silica that combines with alkali and calcium to form $\mathrm{N}, \mathrm{K}-(\mathrm{C})-\mathrm{S}-\mathrm{H}$ gels which is causing extension of the concrete [12]. While the pozzolanic reaction is usually attached to fine glass particles where the silica is released after the devastation of the silica network by the hydroxide ions, combines with calcium from Portlandite to form $\mathrm{C}-(\mathrm{N}, \mathrm{K})-\mathrm{S}-\mathrm{H}$ as shown in Equation $(1,2)$ which works to improve the properties of the concrete [13]. Also [14] mentioned that the glass powders fineness is a primary factor in the glass pozzolan's production to provide their potential interaction.

Cement + water $\rightarrow$ calcium silicate hydrate $(\mathrm{Gel})+$ calcium hydroxide

Equation (1)

Pozzolan + calcium hydroxide + water $\rightarrow$ calcium silicate hydrate $(\mathrm{Gel})$. Equation (2)

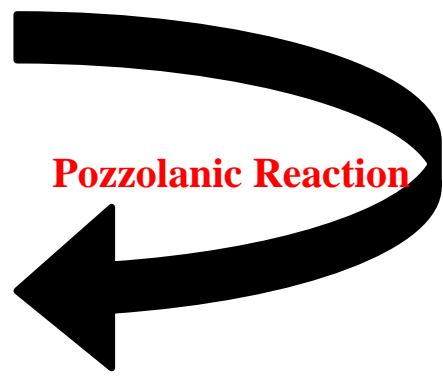


The pozzolanic properties of the glass are clearly observed when the particle sizes are approximately less than $300 \mathrm{Mm}$ and less than 100Mm, glass can have a pozzolanic reactivity at the lowest replacement percentages of cement with glass after the age of 90 days of curing [15], and the Grinding waste glass into micro-sized particles as shown in the Fig.1, for increasing the reactions between the hydrates of cement and the glass, can get a major energy, economic and environmental benefits when cement is partially replaced with grinded waste glass for production of concrete [8].So we can use glass powder for improving environmental harmful effects, and work to improve the various properties of concrete, This size of glass can be obtained by using a grinding operation with the help of (ball mill); which is generally used in cement in dustry to grind cement clinker.

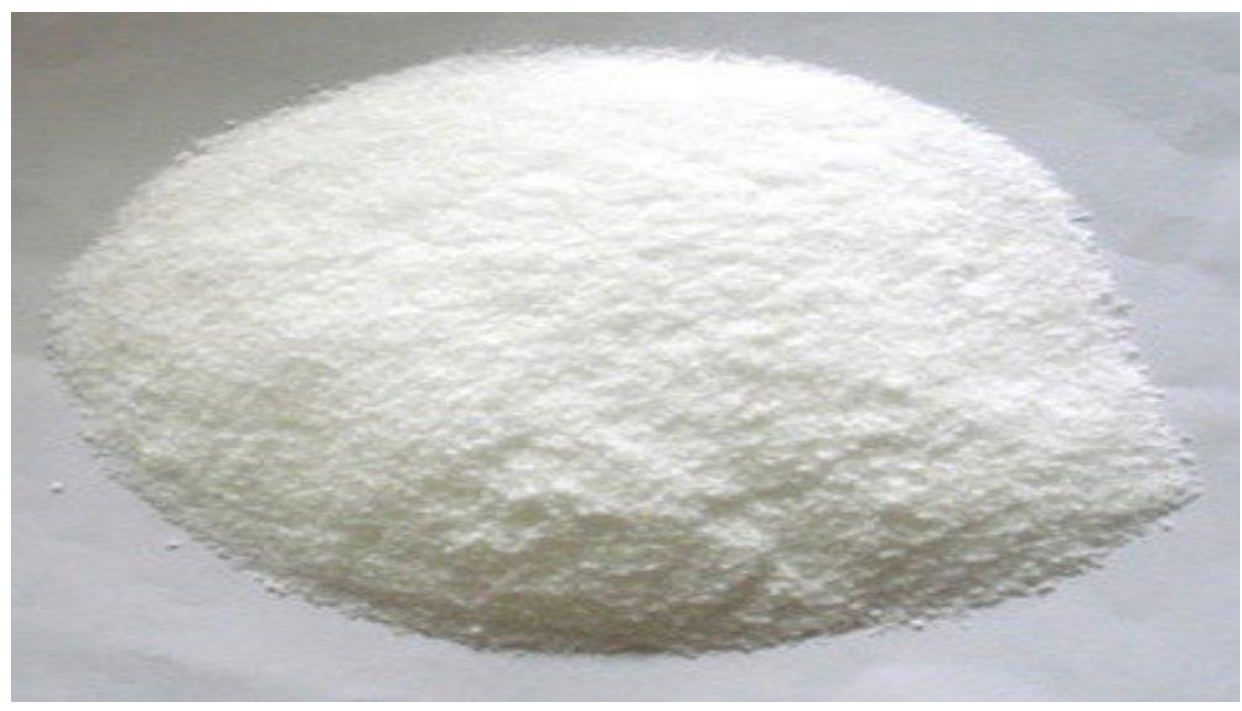

Fig.1: Glass powder.

\section{Research significance}

This research aims to study the effect of the behavior of glass powder on fresh concrete, which is the flow of concrete, as well as some different characteristics of hardened concrete (compressive strength, indirect tensile strength, bond strength) by using sikament $-163 \mathrm{M}$ is used as a super plasticizer by $1 \%$ from weight of cement to produce high-quality concrete with a high water-reduction efficiency.

\section{Experimental Details}

\subsection{Materials}


3.1.1. Cement: Ordinary Portland cement (CEM I-52.5N); N: It symbolizes that this cement takes the time of natural doubt. The same batch of cement was used to cast all of the specimens, cement used was fresh product and achieve the requirements of the Egyptian standard for the physical and mechanical properties of ordinary Portland cement [16].

3.1.2. Fine Aggregates: Sand was used with a fineness modulus of 2.58 and it also has specific gravity of [2.56], the particle distribution curve of sand as well as the limits of the Egyptian standard specifications for concrete aggregates [17].

3.1.3. Coarse Aggregates: The coarse aggregates used is natural dolomite (crushed stone) were sieved to obtain aggregates of various sizes $(5-14 \mathrm{~mm})$, and also it has a specific gravity of [2.78]. The particle distribution curve of coarse aggregates as well as the limits of the Egyptian standard specifications for concrete aggregates [17].

3.1.4. Glass Powder: Glass powder was used as a partial substitute for cement by ratios $(0 \%, 5 \%, 10 \%, 15 \%, 20 \%)$, as the glass was grinded in the laboratories of the research institute in Cairo and the sample was sieved completely and passed through a 75-micrometer sieve, and Table 1 shows the chemical composition of clear glass.

Composition

\begin{tabular}{cc}
\hline $\mathrm{SiO}_{2}$ & 72.42 \\
\hline $\mathrm{Al}_{2} \mathrm{O}_{3}$ & 1.44 \\
\hline $\mathrm{TiO}_{2}$ & 0.035 \\
\hline $\mathrm{Cr}_{2} \mathrm{O}_{3}$ & 0.002 \\
\hline $\mathrm{Fe}_{2} \mathrm{O}_{3}$ & 0.07 \\
\hline $\mathrm{CaO}$ & 11.50 \\
\hline $\mathrm{MgO}$ & 0.32 \\
\hline $\mathrm{Na}_{2} \mathrm{O}$ & 13.64 \\
\hline $\mathrm{K}_{2} \mathrm{O}$ & 0.35 \\
\hline
\end{tabular}


Table

$\frac{\mathrm{SO}_{3}}{\mathrm{Chemical} \mathrm{component} \mathrm{of} \mathrm{a} \mathrm{clear} \mathrm{glass}^{2}}$

1:

3.1.5. Water: The specimens were mixed and cured with potable water. water used for mixing and curing free from acids, sugars, salts, oils and other injurious substances. The $\mathrm{PH}$ value of water from (6.5-8.5).

3.1.6. Super plasticizer: In this experimental program, Sikament - $163 \mathrm{M}$ is used as a super plasticizer to produce high-quality concrete with high waterreduction efficiency. The Experimental dosage $1.0 \%$ by weight of cement. The properties of super plasticizer are shown in Table 2.

Table 2: Properties of Super Plasticizer

\begin{tabular}{cc}
\hline Density (at $\left.20^{\circ} \mathrm{C}\right)$ & $1.200+$ or- $0.005 \mathrm{Kg} / \mathrm{Liter}$ \\
& $($ ASTM C494) \\
\hline Appearance / colour & Brown Liquid \\
\hline Recommended Dosage & $0.6-2.5 \%$ by weight of cement \\
\hline
\end{tabular}

\subsection{Concrete mix design}

In this experimental investigation, the waste glass powder was used as a primary factor of partial replacement of cement. The concrete mixture used control specimens without (WGP) was designed to obtain a characteristic strength of $35 \mathrm{~N} / \mathrm{mm}^{2}$ at the age of 28 days according to ECP 203-2007, design of concrete Mixes [18]. The mixture proportions for $1 \mathrm{~m}^{3}$ in control group without WGP (Group 0), group with various proportions of WGP (Group1) shown in Table 3, 4.

Table 3: Glass powder mixture proportions (G0) for $1 \mathrm{~m}^{3}$.

; Where $\mathrm{W} / \mathrm{C}=0.4$

\begin{tabular}{ccccccc}
\hline Mix & $\begin{array}{c}\text { Cement } \\
\left(\mathrm{kg} / \mathrm{m}^{3}\right)\end{array}$ & $\begin{array}{c}\text { Water } \\
\left(\mathrm{kg} / \mathrm{m}^{3}\right)\end{array}$ & $\begin{array}{c}\text { Crushed } \\
\text { Stone } \\
\left(\mathrm{kg} / \mathrm{m}^{3}\right)\end{array}$ & $\begin{array}{c}\text { Sand } \\
\left(\mathrm{kg} / \mathrm{m}^{3}\right)\end{array}$ & $\begin{array}{c}\text { Glass } \\
\text { Powder } \\
\left(\mathrm{kg} / \mathrm{m}^{3}\right)\end{array}$ & $\begin{array}{c}\mathrm{SP} \\
\left(\mathrm{kg} / \mathrm{m}^{3}\right)\end{array}$ \\
\hline Mix (0\%GP) & 350 & 140 & 1330 & 675 & Zero & 3.5 \\
\hline
\end{tabular}


Table 4: Glass powder mixture proportions (G1) for $1 \mathrm{~m}^{3}$.

; W/Binder $=\mathrm{W} /($ cement+ glass powder $)=0.4$

\begin{tabular}{ccccccc}
\hline Mix & $\begin{array}{c}\text { Cement } \\
\left(\mathrm{kg} / \mathrm{m}^{3}\right)\end{array}$ & $\begin{array}{c}\text { Water } \\
\left(\mathrm{kg} / \mathrm{m}^{3}\right)\end{array}$ & $\begin{array}{c}\text { Crushed } \\
\text { Stone } \\
\left(\mathrm{kg} / \mathrm{m}^{3}\right)\end{array}$ & $\begin{array}{c}\text { Sand } \\
\left(\mathrm{kg} / \mathrm{m}^{3}\right)\end{array}$ & $\begin{array}{c}\text { Glass } \\
\text { Powder } \\
\left(\mathrm{kg} / \mathrm{m}^{3}\right)\end{array}$ & $\begin{array}{c}\mathrm{SP} \\
\left(\mathrm{kg} / \mathrm{m}^{3}\right)\end{array}$ \\
\hline $\operatorname{Mix}(5 \% \mathrm{GP})$ & 332.5 & 140 & 1330 & 675 & 17.5 & 3.5 \\
\hline $\operatorname{Mix}(10 \% \mathrm{GP})$ & 315 & 140 & 1330 & 675 & 35 & 3.5 \\
\hline $\operatorname{Mix}(15 \% \mathrm{GP})$ & 297.5 & 140 & 1330 & 675 & 52.5 & 3.5 \\
\hline $\operatorname{Mix}(20 \% \mathrm{GP})$ & 280 & 140 & 1330 & 675 & 70 & 3.5 \\
\hline
\end{tabular}

\subsection{Specimen Preparation.}

Cubes $(100 \mathrm{~mm} \times 100 \mathrm{~mm} \times 100 \mathrm{~mm})$ were cast for compressive strength, prism specimens (100 mm X $100 \mathrm{~mm}$ X $500 \mathrm{~mm}$ ) were cast for flexural strength, Cylinders (Diameter; $150 \mathrm{~mm}$ and height; $300 \mathrm{~mm}$ ) were cast for flexural strength and modulus of elasticity tests; whereas cubes $(150 \mathrm{~mm} \times 150 \mathrm{~mm} \times 150 \mathrm{~mm})$ were cast for water penetration test, Also cubes $(100 \mathrm{~mm} \times 100 \mathrm{~mm} \times 100 \mathrm{~mm})$ were cast for X-Ray Diffraction (XRD).

\section{Test results and discussion}

\subsection{Fresh Concrete.}

\subsubsection{Effect of using glass powder on the consistency.}

A slump test was performed for the control sample as well as for other samples containing different percentages of glass powder; Fig. 2 its show that the slump value of control mix give value of $35 \mathrm{~mm}$ compare to concrete mix with waste glass powder of $5 \% \mathrm{GP}$ is $44 \mathrm{~mm}, 10 \%$ GP is $57 \mathrm{~mm}, 15 \%$ GP are $65 \mathrm{~mm}$ and $20 \mathrm{GP} \%$ are $70 \mathrm{~mm}$. Slump flow test was done according to Egyptian Code for the design and implementation of concrete structures, tests guide C203 [19].As shown in Fig.2, the results clearly indicate that the concrete consistency increased when the percentage of glass powder in the mixing increased, and this also indicates an increase in the workability. 
The increase in workability can be explained with the increase in the proportion of the glass powder in the mixture, and this is due to the crystalline property of the glass is a non-water absorbent material.

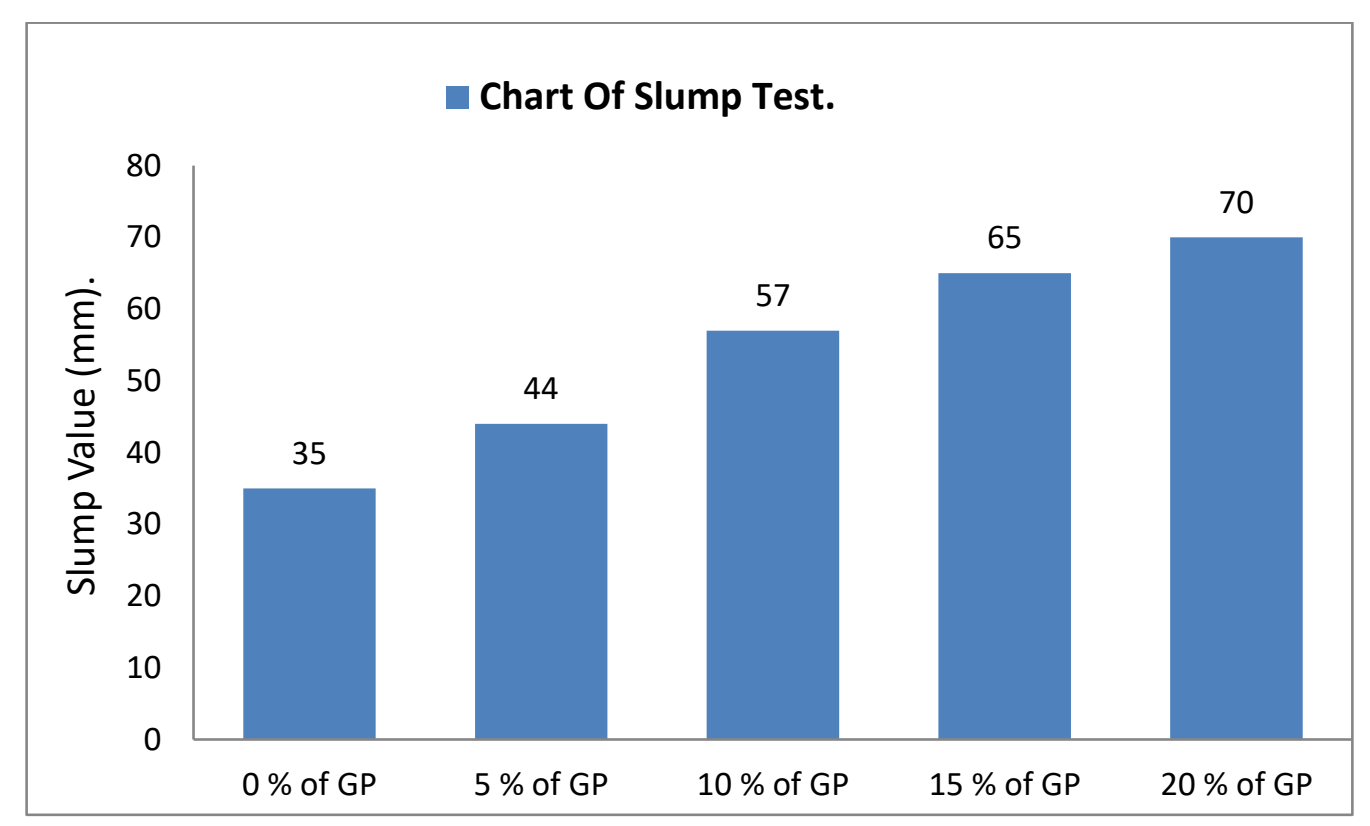

Fig.2: Slump value of all samples.

\subsection{Hardened Concrete}

\subsubsection{Compressive strength}

At the end of 7 days, 28 days and 56 days, the cube specimens were tested for compressive strength without glass powder $(0 \%)$ and with glass powder by percentages $(5 \%, 10 \%, 15 \%, 20 \%)$. The compression test is carried out in a compression testing machine with a capacity of $2000 \mathrm{KN}$ and a loading rate of $0.6 \mathrm{~N} / \mathrm{mm}^{2} / \mathrm{sec}$ as shown in Fig.3, according to Egyptian Code for the design and implementation of concrete structures, test guide C203 [19]. Table 5 were presented the results of compressive, and the results confirmed an increase in the compressive strength of concrete in all ages and at all proportions of replacing cement with glass powder compared to the control sample, except for the sample containing $20 \%$ of glass powder was less than the control sample at all ages. The best replacement ratio was 15\% of GP because it gave the highest improvement value of compressive strength, this improvement of concrete strength reached at the age of 28 days a value of $28.6 \%$ cement, and $32.4 \%$ at the age of 56 days.

The explanation for this increase in compressive strength is that the glass powder is a pozzolanic material that interacts with cement hydrate, forming calcium silicate 
hydrate $(\mathrm{C}-\mathrm{S}-\mathrm{H})$, a substance that increase the bonding and cohesion between the grains, also the glass powder fills the voids, making the concrete dense and this leads to enhance in the compressive strength.

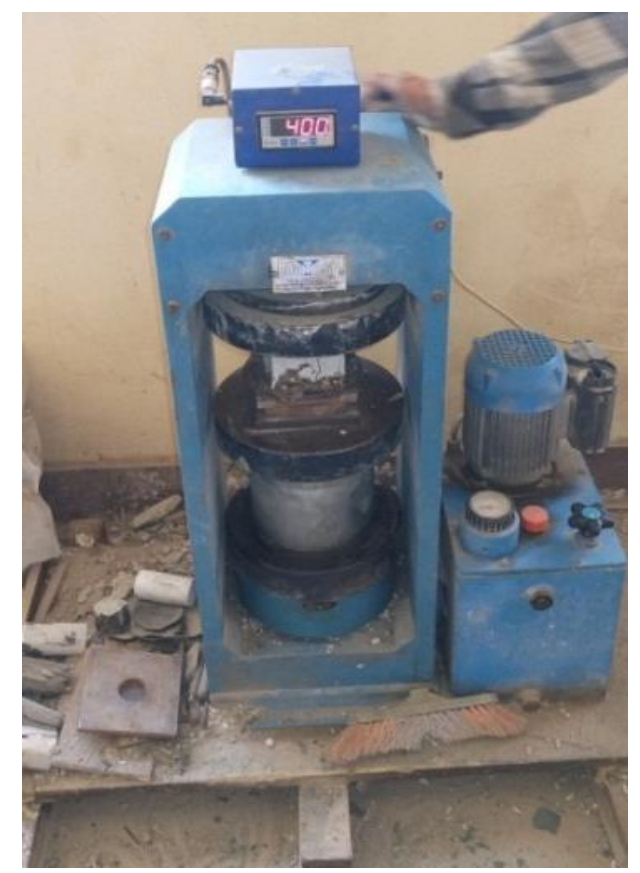

Fig.3: Compressive strength test procedure.

Table 5: The results of compressive strength at different ages.

\begin{tabular}{lllll}
\hline \multirow{2}{*}{ Mix } & \multirow{2}{*}{$\begin{array}{l}\text { \% of glass powder } \\
\text { replacement }\end{array}$} & \multicolumn{3}{c}{ Compressive strength $\left(\mathrm{N} / \mathrm{mm}^{2}\right)$} \\
\cline { 3 - 5 } & & 7 days & 28 days & 56 days \\
\hline 1 & $0 \%$ & 28.5 & 39.8 & 44.4 \\
\hline 2 & $5 \%$ & 29.5 & 40.8 & 46.9 \\
\hline 3 & $10 \%$ & 33 & 44.5 & 51.5 \\
\hline 4 & $15 \%$ & 35.5 & 51.2 & 58.8 \\
\hline 5 & $20 \%$ & 25.2 & 35.4 & 40.3 \\
\hline
\end{tabular}

\subsubsection{Flexural strength test}

The flexural strength test was performed on prism specimens $(100 \mathrm{~mm}$ X $100 \mathrm{~mm} \mathrm{X}$ $500 \mathrm{~mm}$ ) after curing in fresh water at $20^{\circ} \mathrm{C}$ at the age of 28 days. In the R.C laboratory of Al-Azhar university, all prism specimens were tested under four point static load according to Egyptian Code for the design and implementation of concrete structures, tests guide C203 [19], using a $1000 \mathrm{kN}$ capacity (loading rate $0.06 \mathrm{~N} / \mathrm{mm} 2 / \mathrm{sec}$ ) 
hydraulic jack mounted on a steel frame. The results achieved an increase in the flexural strength of concrete with an increase in the percentages of glass powder to a certain extent of $15 \%$, and then it declines at $20 \%$ of glass powder.

The optimum glass powder replacement percentages for flexural strengths have been found to be 15\% as shown in Fig.4, where it achieved an increase in flexural strength at the age of 28 days reached up to $21.58 \%$ compared to the control sample, while the sample containing 5\% GP increased by $3.24 \%$, and the sample containing $10 \%$ GP increased by $12.41 \%$ from control sample. Therefore, it is possible to use glass powder in the concrete mix at a replacement rate of $15 \%$ of cement, because it enhances the flexural strength of concrete.

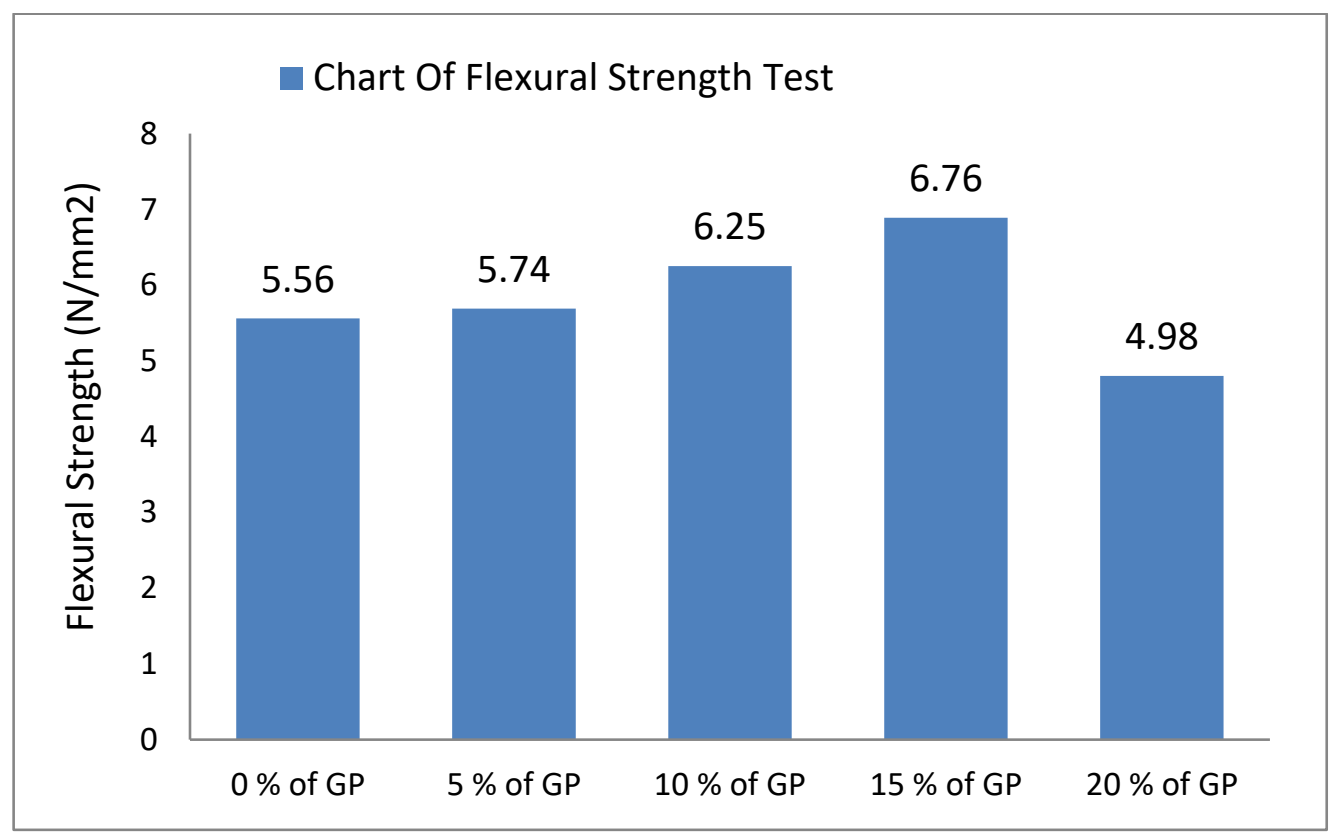

Fig.4: Effect of glass powder on flexural strength of concrete.

\subsubsection{Water penetration resistance of concrete}

The water penetration test for concrete was conducted in the reinforced concrete laboratory at new Cairo academy according to BS-EN 12390-8 [20] after 28 days of curing. For each test three cubes with dimension $(150 \mathrm{~mm} \times 150 \mathrm{~mm} \times 150 \mathrm{~mm})$ were prepared and the samples were placed in the test device after roughening the surface of the samples with a wire brush that will be exposed to water pressure. After installing the samples in the device, they were exposed to $5 \mathrm{Bar}(500 \mathrm{KPa})$ water pressure and the test continued for 72 hours. At the end of the test period, the samples were divided into two parts and the water penetration into the sample was measured. A result of the test was the greatest depth of water penetration into the sample.

The results clearly indicated a decrease in water permeability to the sample by increasing the percentage of waste glass powder in the concrete sample as shown in 
Fig.5, because the glass powder filled a large proportion of voids, and in addition to the fact that glass is a non- water absorbent material.

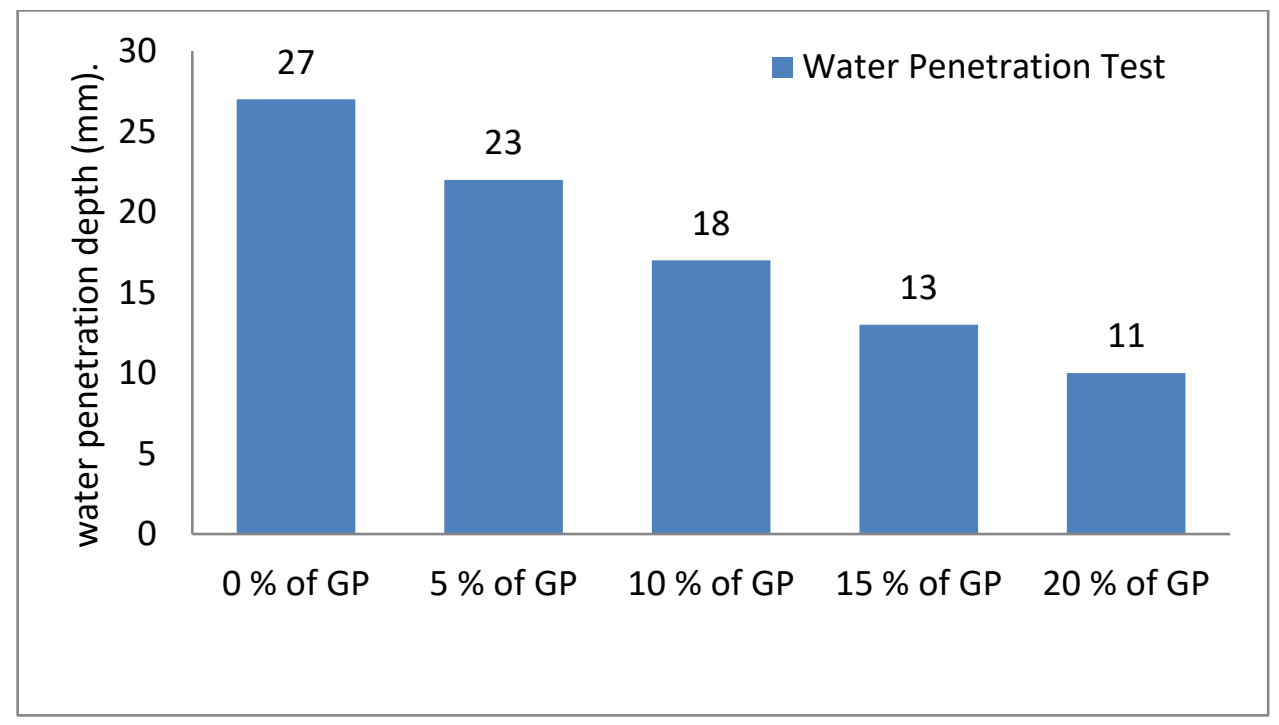

Fig.5: shows the depth of water penetration for all samples.

\subsubsection{Modulus of Elasticity test}

According to the Egyptian Code for the design and implementation of concrete structures, tests guide C203 [19], the modulus of elasticity was calculated by subjecting a cylinder sample (diameter $150 \mathrm{~mm}$, height $300 \mathrm{~mm}$ ) to uniaxial compression using a Universal Testing Machine with a capacity of $1000 \mathrm{Kn}$. A Keithley-500A Data Acquisition System consists of 4 channels for strain measurement and corresponding load. The deformations were measuring by dial gauges were fixed between certain gauge lengths as shown in Fig.6. The Modulus of elasticity was found out by the initial tangent drawn from the origin for the stress-strain curve Fig.7 to Fig.11.Table 6 shows the value of modulus of elasticity for reference mixture (Mix- 0\% GP) and mixtures; (Mix-5\% GP, Mix-10\% GP, Mix-15\% GP and Mix-20\% GP) at age 28 days.

This test confirmed that good results were obtained from the use of glass powder in the concrete mixture, because it was noted that by increasing the percentage of glass powder in the mixing, the modulus of elasticity increased until the percentage of replacing $15 \%$ of the glass powder as a partial replacement of cement and after that it declined (sample containing 20\% glass powder). The percentage of increase in the modulus of elasticity compared to the control sample of mixture; $5 \%$ GP, Mix-10\% GP and Mix-15\% GP were as follow: $8.18 \%, 22.86 \%$, and 37.9\%, respectively. However, it decreased $7.8 \%$ for the sample containing $20 \%$ of glass powder. 


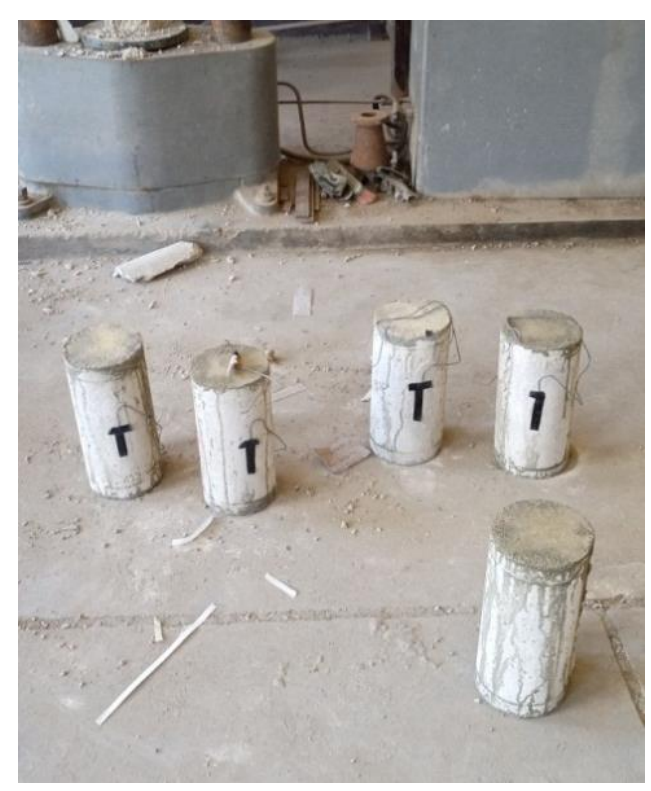

Fig.6: Showing the strain gauge used on the samples.

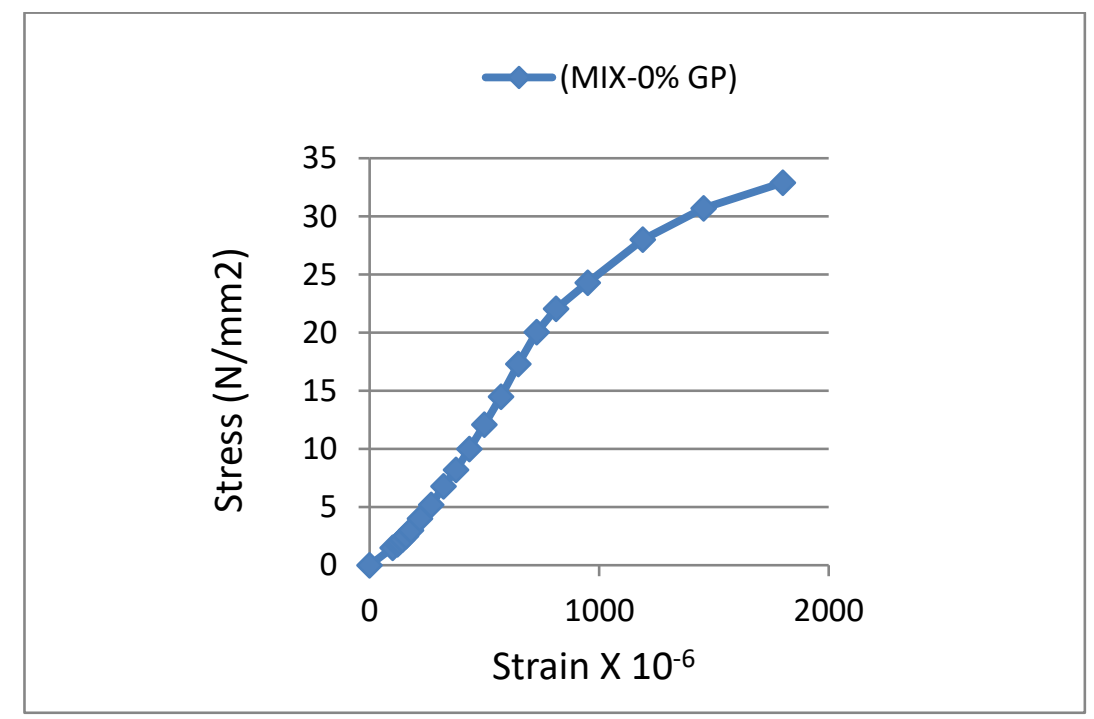

Fig.7: stress strain curve for control mixture Mix- 0\% GP. 


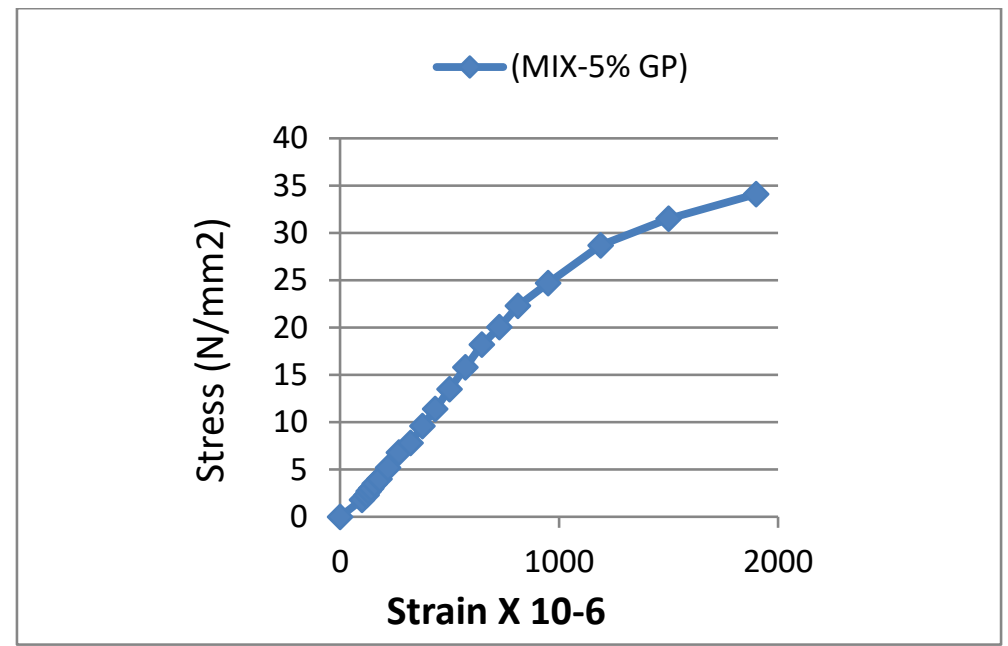

Fig.8: stress strain curve for mixture Mix-5\% GP

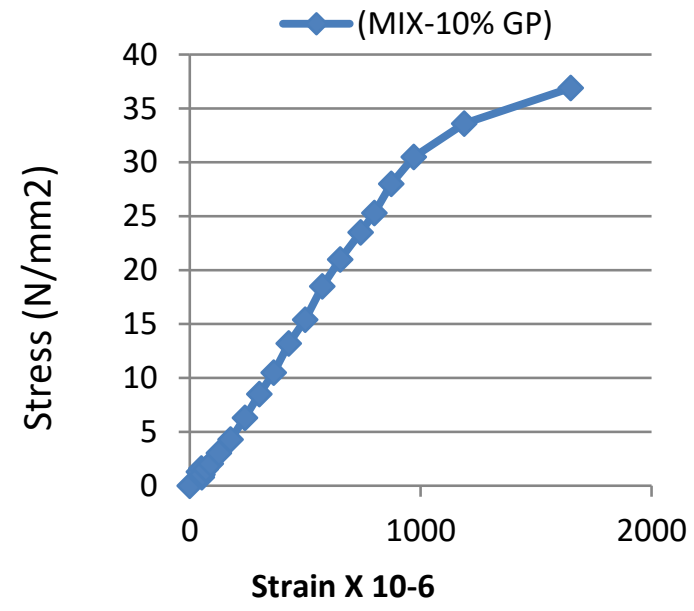

Fig.9: stress strain curve for mixture Mix-10\% GP.

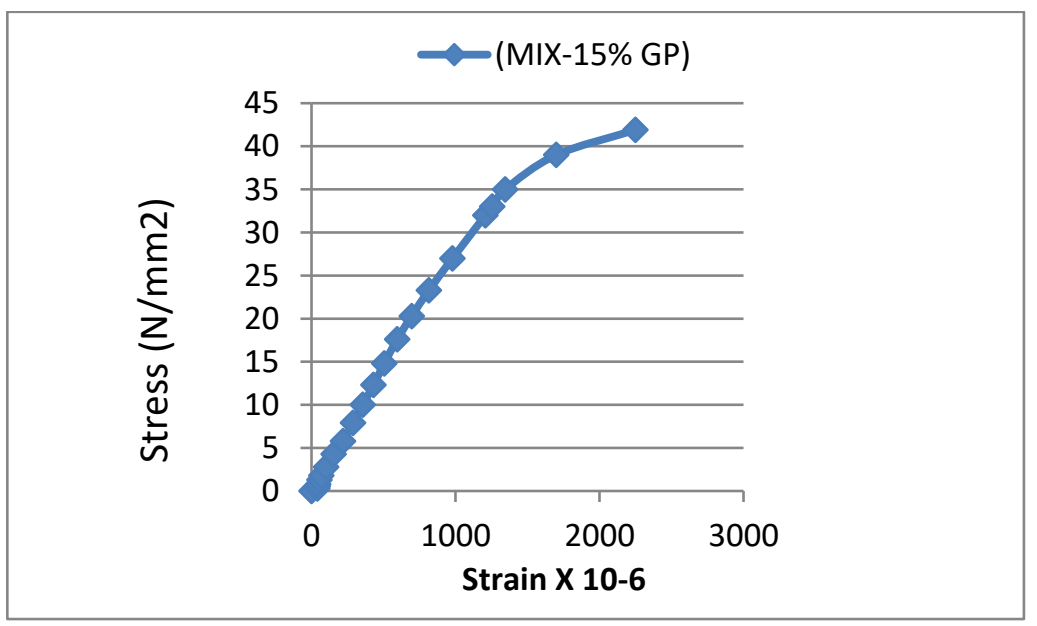

Fig.10: stress strain curve for mixture Mix-15\% GP. 


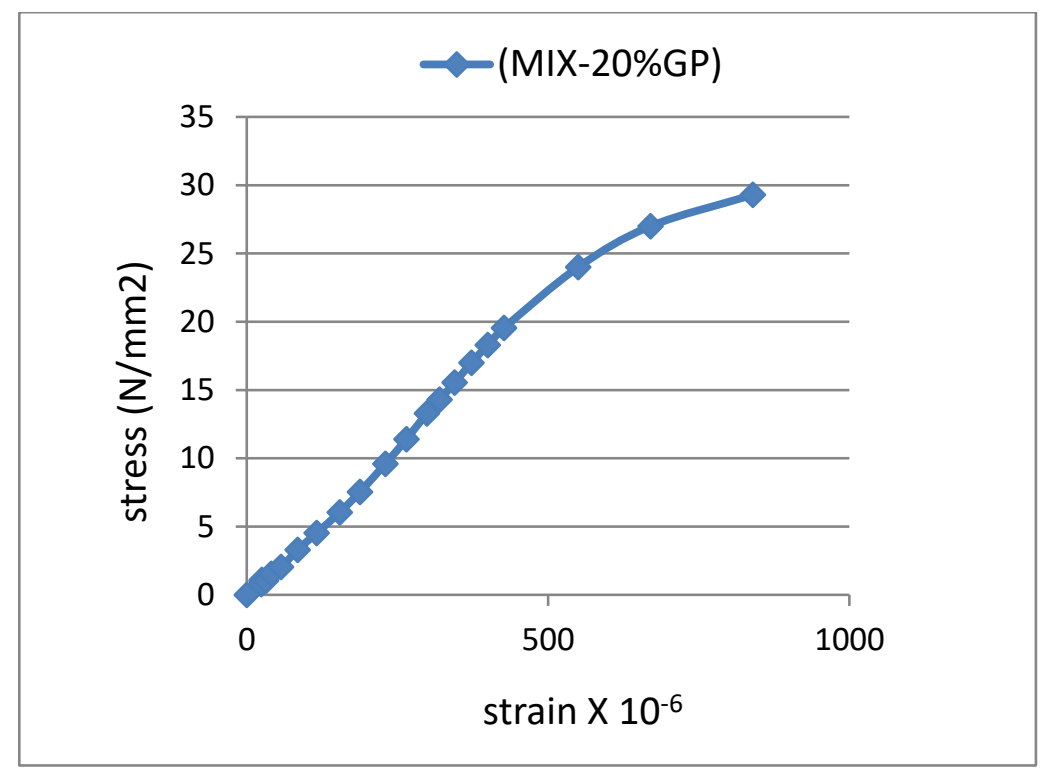

Fig.11: stress strain curve for mixture Mix-20\% GP.

\begin{tabular}{|l|l|}
\hline Mixture & $\begin{array}{l}\text { Modulus of elasticity } \\
\text { (N/mm2) }\end{array}$ \\
\hline Mix- 0\% GP & 27190.6 \\
\hline Mix- 5\% GP & 29414.4 \\
\hline Mix- 10\% GP & 33407.53 \\
\hline Mix- 15\% GP & 37494.39 \\
\hline Mix- 20\% GP & 25048.62 \\
\hline
\end{tabular}

Table 6: Modulus of elasticity results

\subsubsection{XRD analysis test}

The test was conducted at Housing and Building National Research Center in Cairo, The X-ray diffraction (XRD) identifies and measures the presence and amounts of minerals and their species in the sample, as well as identifies phases. Both samples were grinded then the X-ray diffraction (XRD) analysis was carried out for two samples; the first sample is the control sample and the second sample is the one that gave the best results for strengths, which contain 15\% glass powder. Fig.12, 13 presented the results of X-ray diffraction (XRD) for the control sample and the sample containing $15 \%$ GP, respectively. The results actually confirmed the occurrence of a pozzolanic reaction and forming secondary Calcium Silicate Hydrate $(\mathrm{C}-\mathrm{S}-\mathrm{H})$ which enhances cohesion between the grains, Because we discovered that sample containing glass particles $(15 \%)$ as a partial replacement for cement have lower calcium hydroxide content than sample made entirely of cement, owing to the occurrence of the pozzolanic reaction, which may contribute to [21]. This explains the benefits in the mechanical properties related to durability. 


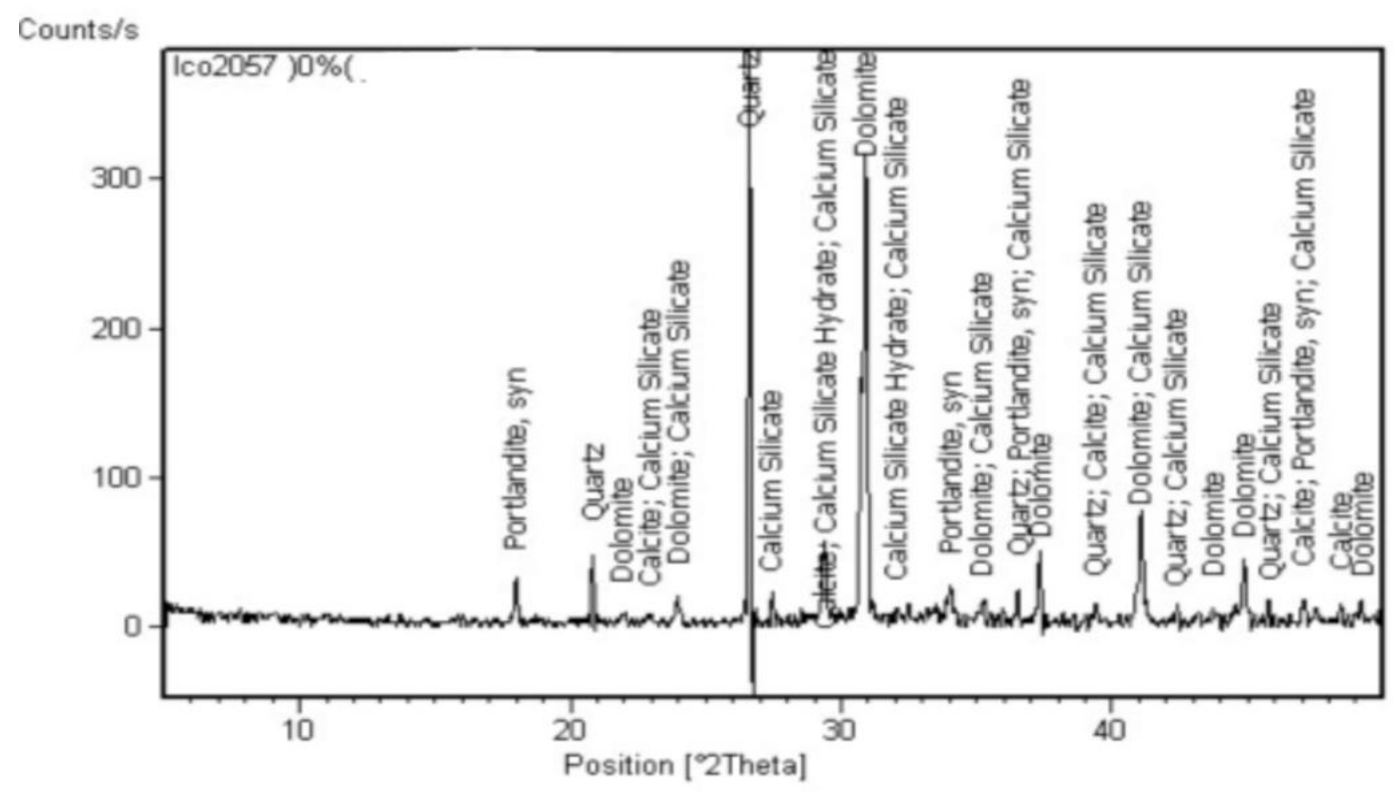

Fig.12: XRD analysis for control sample.

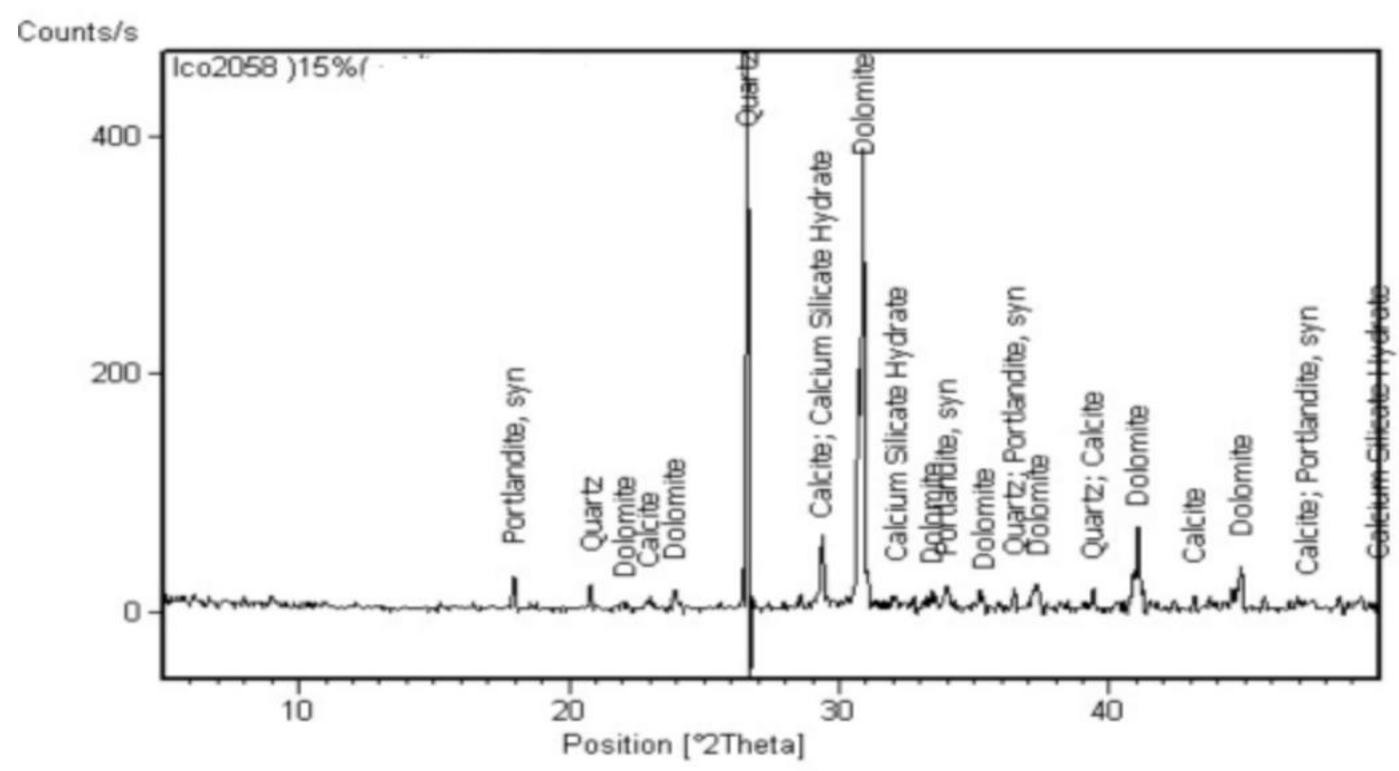

Fig.13: XRD analysis for mixture sample $15 \% \mathrm{GP}$.

\section{SUMMARY AND CONCLUSIONS}

After conducting laboratory experiments for control sample and samples containing glass powder with the help of super plasticizer (Sikament - 163M), several observations were reached from these experiments, as follows. 
1) A noticeable increase in the workability of concrete with an increase in the percentage of WGP in the mixing, and that is a matter logically, because glass is agglomeration material and does not absorb water.

2) Compressive strength increases with the increase in percentage of WGP up to $15 \%$ replacement and then declined. The percentage $15 \%$ replacement achieved good improvement at the age of 28 and 56 days reached to $28.6 \%, 32.4 \%$ respectively, compared to the control sample.

3) Flexural strength increases by increasing the percentage of WGP in the mixing until we reach a percentage of replacement of $15 \%$; this percentage is the optimum percentage as it achieved the highest increase in flexural strength; this increase reaches $21.58 \%$ at the age of 28 days compared to the control sample. Then it decreased at a replacement rate $20 \%$ of WGP.

4) The depth of water penetration decreases significantly with the increase in the percentage of WGP in the concrete mix, because the glass powder filled a large proportion of voids, and in addition to the fact that glass is a non- water absorbent material.

5) The results confirmed the good effect of using the glass powder on the modulus of elasticity of concrete, where the modulus of elasticity increases by increasing the WGP in the mixing until the proportion of replacing $15 \%$ of the glass powder, which is the optimum proportion of the glass powder achieved the highest increase and the increase was $37.9 \%$ compared to the control sample and then decreased when at a $20 \%$ replacement rate.

6) XRD test actually proved that a pozzolanic reaction occurred between the glass powder and cement hydrate forming secondary Calcium Silicate Hydrate $(\mathrm{C}-\mathrm{S}-\mathrm{H})$ secondary, which increases the cohesion between the grains of the sample.

NOTE: All the strengths increase when the percentage of glass powder in the mixing is increased and this increase in strength continues until we reach a percentage of replacement of $15 \%$ of the glass powder, because the glass powder is a pozzolanic substance that interacts with cement hydrate to form $(\mathrm{C}-\mathrm{S}-\mathrm{H})$ secondary, which enhances the bonding between the grains, and the glass powder also fills the voids, making the concrete more dense and increases the strength of the concrete but this increase is to a certain extent only $15 \% \mathrm{GP}$, and then it decreases. The explanation for this decrease in strength at $20 \%$ replacement of GP is because by increasing the replacement ratio by more than $15 \%$ GP, it leads to a decrease in the cement content by an amount that affects the interaction of the cement, so the energy resulting from interaction decreases, which also leads to a decrease in the formation of the basic (C-S$\mathrm{H})$ responsible for the interconnection between the grains and giving the concrete element its required resistance. 


\section{REFERENCES}

1. T. R. Naik, "Sustainability of concrete construction," Practice Periodical on Structural Design and Construction, vol. 13, pp. 98-103, 2008.

2. M. S. Imbabi, C. Carrigan, and S. McKenna, "Trends and developments in green cement and concrete technology," International Journal of Sustainable Built Environment, vol. 1, pp. 194-216, 2012.

3. G. S. Islam, M. Rahman, and N. Kazi, "Waste glass powder as partial replacement of cement for sustainable concrete practice," International Journal of Sustainable Built Environment, vol. 6, pp. 37-44, 2017.

4. R. J. Detwiler, J. I. Bhatty, and S. Battacharja, Supplementary cementing materials for use in blended cements, 1996.

5. J. Ryou, S. P. Shah, and M. Konsta-Gdoutos, "Recycling of cement industry wastes by grinding process," Advances in applied ceramics, vol. 105, pp. 274279, 2006.

6. H. Binici, O. Aksogan, I. H. Cagatay, M. Tokyay, and E. Emsen, "The effect of particle size distribution on the properties of blended cements incorporating GGBFS and natural pozzolan (NP)," Powder Technology, vol. 177, pp. 140147, 2007.

7. P. Soroushian, "Strength and durability of recycled aggregate concrete containing milled glass as partial replacement for cement," Construction and Building Materials, vol. 29, pp. 368-377, 2012.

8. A. M. Rashad, "Recycled waste glass as fine aggregate replacement in cementitious materials based on Portland cement," Construction and building materials, vol. 72, pp. 340-357, 2014.

9. I. E. Agency and I. E. Agency, Tracking industrial energy efficiency and $\mathrm{CO} 2$ emissions: Organisation for Economic Co-operation and Development, 2007.

10. C. Du Plessis, "A strategic framework for sustainable construction in developing countries," Construction management and economics, vol. 25, pp. 67-76, 2007.

11. R. Idir, M. Cyr, and A. Tagnit-Hamou, "Potential pozzolanicity of glass cullet fines and aggregates," in Annales du Bâtiment et des Travaux Publics, 2011, pp. 28-34.

12. Y. Shao, T. Lefort, S. Moras, and D. Rodriguez, "Studies on concrete containing ground waste glass," cement and concrete research, vol. 30, pp. 91-100, 2000.

13. A. Carles-Gibergues, M. Cyr, M. Moisson, and E. Ringot, "A simple way to mitigate alkali-silica reaction," Materials and Structures, vol. 41, pp. 73-83, 2008.

14. L. A. Pereira-de-Oliveira, J. P. Castro-Gomes, and P. M. Santos, "The potential pozzolanic activity of glass and red-clay ceramic waste as cement mortars components," Construction and Building Materials, vol. 31, pp. 197-203, 2012.

15. C. Shi, Y. Wu, C. Riefler, and H. Wang, "Characteristics and pozzolanic reactivity of glass powders," Cement and Concrete Research, vol. 35, pp. 987993, 2005.

16. (The Egyptian Standard Specifications, 2421-1993).

17. The Egyptian standard specifications for concrete aggregates 1109/2002.

18. ECP 203-2007. (2007). Egyptian code for design and construction of reinforcedconcrete structures, Design of Concrete Mixes (2-28) to (2-34). 
19. The Egyptian Code for the design and implementation of concrete structures, tests guide $\mathrm{C} 203$.

20. The British Standard Specifications for hardened concrete tests (BS-EN 12390Part8).

21. P. K. Mehta and P. J. M. Monteiro, Concrete: Microstructure, Properties, and Materials, McGraw-Hill Education, New York, NY, USA, Fourth Edition, 2014. 